\title{
A New perspective to the Process of Education/Communication in the Era of Digital Technologies
}

\section{Cury, Lucilene ${ }^{\mathrm{a}}$ and Cesar Sousa, Paulo}

${ }^{\mathrm{a}}$ University of São Paulo, Brazil, ${ }^{\mathrm{b}}$ Postgraduate Program in Integration of Latin America, University of São Paulo, Brazil.

\begin{abstract}
This paper aims to discuss the challenges of higher education regarding the relationship between the university and the individual in the era of Information and Communication Technologies (ICTs). It proposes a new teaching-learning model that allows establishing an educational and transformative communication between university-student. Therefore, it is imperative to consider that technology by itself adds little to the construction of new knowledge and, in this sense, the university can wave towards the establishment of a new paradigm in the education-student relation. In order to justify this proposal, this paper will analyze how the course "Theory and Method of Research in Communication, taught in face-to-face format for the undergraduate students of the School of Communications and Arts of the University of São Paulo, will be converted into a distance-learning course. This conversion will contribute with the formation of new researchers in the scientific field and consequently with the democratization of knowledge. As it can be observed, the mass use of the e-learning modality in Brazil presents itself as a potential tool for consolidating this new teaching-learning model, when associated with the communication process.
\end{abstract}

Keywords: Education/ Communication; ICTs; teaching-learning model; participative-student; dialogue. 


\section{Introduction}

The consolidation of digital technologies in recent decades has completely altered our relationship with the environment and the way we perceive our presence in the world. Because of the technological impact, the communication resources used in education are under constant modifications by this technological revolution, which has affected the teaching-learning process in the most varied areas of knowledge. The technology also allowed the university to expand its space beyond its physical limits. Up to this moment, considered as a modality of education distinct from the face-to-face format, distance education has proven its effectiveness in the educational system. In Brazil, the Distance Education 2016 Census showed that it is already possible to find a wide range of programs of different levels at most of the three hundred and forty educational institutions that participated in the research. This is fact turns evident the search for education to supply the new needs imposed by information and communication technologies (ICTs).

The impact of digital technologies on educational transformation is happening all over the world, as in the case of Complutense University of Madrid, which since 2014 has expanded beyond its physical walls by joining the production of MOOC (massive, open, online course) in the most varied areas of knowledge, in collaboration with other universities in Europe and the United States. The use of ICTs in Education can also be observed in Portugal, which has expanded access to higher education, especially through e-learning by the so-called Open Universities, as Tibiriçá (2015) observes. Although these repercussions are very positive, Peruvian sociologist Maria Teresa Quiroz draws attention to the fact that, even with all these changes brought about by the internet, classrooms still expresses the same educational practices focused on the transmission of knowledge. For her, the quality of education is not only about the use of technology, "but about thinking and attitude that allows a more flexible, personalized and ubiquitous school" (Quiroz, Maria Teresa, 2015). According to Aparici (2014), "methodological changes, which seeks for new pedagogical models, and interactive practices based on dialogue are issues that are beyond a certain technology or another." In this sense, despite all the technological apparatus available in our daily lives, education still makes use of the old pedagogy of transmission that treats the student as passive issuer in the communication process. Recognizing this, Prieto Castillo (2000) states that "communication in education goes far beyond the use of the means in teaching. We are interested in communication in the work of the educator, in the work of the student and in the means and materials used ".

In view of these observations, it is evident that, even with the possibilities of using the current available technological apparatus, higher education continues to treat the student as a passive receiver within the communication process. It is, therefore, up to the higher education institutions to broaden the debate about the teaching-learning process in order to rethink the relations that are being established between student-university regarding the 
possibilities of the use of technology. For this reason, it is necessary to intensify the search for new methods that allow the establishment of a new communication process based on the dialogue as proposed by Freire (1973), so that the model based solely on the transmission, be surpassed and reaches a new pedagogical conception, able to lead to understanding through new ways and languages of communication.

\section{Reflections about the Process of Education/Communication}

The present paper proposes to make a brief critical analysis of the communication process established between the individual and the university in the face of this new need imposed by digital technologies.

In the historiography of education both the concept of space and time are dichotomous. This is due the fact that space is an essential component for the existence of any activity, while its occupation is converted in the place where such action is or will be developed. Viñao Frago and Escolano (2001) stated that "where one learns and one teaches, is always a place, one creates a place. However, such a place may vary in time for the students and for the professor", which corroborates for the place where the educational institution is operating also becomes part of the process of formation of the student. This happens because the teaching-learning process is changeable and follows the evolution of each era. In this sense, the space always communicates, shows how the humans being use it according to each culture and in this way, the dialogue between space and the individual can be perceived through the signs that are arranged in each place. In view of this, it is the duty of the educator to query the effectiveness of the current means used by the educational institution in the communication and teaching-learning processes.

Kaplún (2014) argues that education, in order to meet contemporary demands, must be able to activate the potentialities of self-learning and co-learning and stimulate the autonomous management of students in their learning to learn process. Thus, for such processes to advance, it is necessary for Education to develop tools capable of stimulating and motivating the students, transforming them into communicators, allowing them to develop self-expression and discover their abilities during the teaching-learning process. Hence, it is necessary that the digital literacy of our students, those included and excluded in cyberspace, as well as of our professors be considered in the discussion about access to ICTs as defended by Gutiérrez Martín Afonso (2014). Consequently, the development of this new method of literacy is one of the paths that can and must be pursued so that educational communication between higher education and the individual be established and that the collective intelligence be mobilized. 


\section{The Dialogical Relation as Advancement in the Teaching-learning Process}

It is necessary to question the noises of communication between education and the student, since the traditional structure of education slowly follows the language used by the student is his/her daily life. In this sense, the school has the mission of adapting its space to the communicational necessity imposed by the digital culture. In the words of Nóvoa (2015), "it is necessary to rebuild a culture of debate and criticism marked by interaction, dialogue, joint reading our work, and for the capacity to engage in an intellectual conversation with others." Although this task is quite challenging, one cannot ignore the fact that education has adapted to the realities of each era, and has established itself throughout times as an institution that forms individuals. It is possible to observe that the university already moves towards the use of these new elements. However, in order to such actions allow educational institutions a fluent dialogue with the language of the student of our days, it is necessary to understand the differences between information, knowledge and wisdom as proposed by Cury (2012), when revisiting Morin's work. In distance education, for example, we can find elements that support or not the necessities of dialogue in this new scenario. In this sense, Crovi Druetta (2014) draws attention to the fact that "despite theoretical, methodological and technological advances, modern networked-distance education systems do not always have a transformative and dialogic perspective of a learning network". Considering this demand, it is possible to observe that the programs offered through distance education in Brazil and the number of students they have attracted are quite expressive as the graphs obtained by the Distance Education
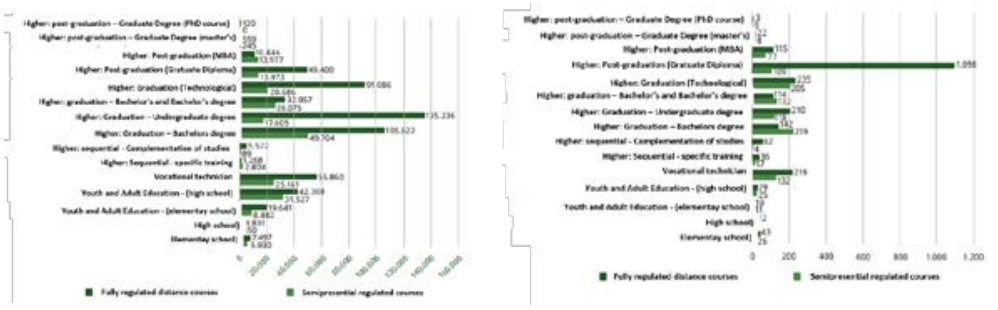

Census shows:

Figure 1. The graphics show, respectively, the numbers of enrolments and the programs offering in absolute numbers categorized by academic level. Source: Brazilian Association for Distance Education. (Org.). (2016). Censo EAD.BR: analytic report of distance learning in Brazil 2016 [Digital version Adobe Reader] (M. T. M. Abreu, Trad.). Recovered from http://abed.org.br/censoead2016/Censo_EAD_2016_portugues.pdf. [Translated by Maria Thereza Moss de Abreu].

Although such an educational modality makes use of instruments compatible with the digital era, these resources must be in harmony with pedagogical practices that make the student the protagonist of his own learning. Faced with this necessity, a proposal was made to adapt the course "Theory and Method of Research in Communication”. Taught in a face- 
to-face format for the undergraduate students of the School of Communications and Arts of the University of São Paulo, this course will be converted into a distance-learning course, which can broaden the training of researchers in the scientific field and, consequently, lead to knowledge democratization. In the face-to-face format, the course is offered annually in the first semester. It has a workload of 60 hours developed in the period of one semester (6 months), for an approximate number of 60 students. The course will be based on expository classes, readings and text reports, teamwork, advising inside and outside the classroom, preparation and execution of a collective research project. The teaching work will be done alongside master's degree and $\mathrm{PhD}$ students, who, in addition to in-depth seminars on topics developed in class and other didactic activities, will provide fundamental support by accompanying the educational process. To meet the proposed learning objectives, the contents are divided as follows: Class 1: Presentation of the course and indication of the changings to begin the process of teaching / learning of scientific research. Class 2: Discussion of the main points of the movement, with notes towards the deep phases of the process. Class 3: The classic science -René Descartes. Class 4: The epistemology of complex thinking - Edgar Morin. Class 5: The question of the research problem - Karl Popper. Class 6: Present examples of research problems to orient students on choosing their topics as well as its respective problems. Class 7: The definition of the research topics and problems chosen, as well as their demarcation, in order to verify their research viability. Class 8: The phases and stages of a research project - Lucilene Cury. Class 9: Starting to design the project. Class 10: Finalization and presentation of projects. In order to meet the proposed pedagogical purposes, the course, which is offered as a sixty-hour in-person course will be divided into two modules in the e-learning format, being one module theoretical and the other practical, with 10 lessons each in a period up to 12 months. The structure planned for the course is displayed in the figure below:

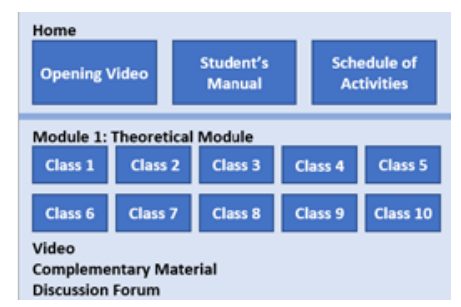

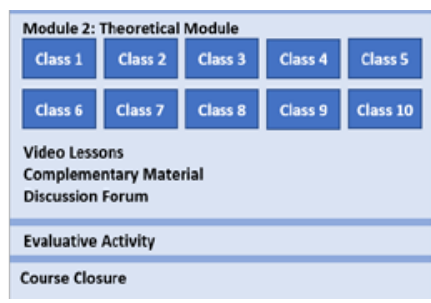

Figure 2. Structure of the course Theory and Method of Research in Communication for the e-learning format. Source: Cury, L., Sousa, P. C., \& Kudeken, V. S. S, (2017). Proposta de Curso na Modalidade Ead - Introdução à Pesquisa Científica a partir da Disciplina Teoria e Método de Pesquisa em Comunicação da ECA/USP. doi: 10.17143/ciaed/XXIIlCIAED.2017.00420 
As can be seen in figure 2 above, the student can make use of different learning resources to obtain appropriate knowledge. For this to be possible, there will be used the Active Methodology so that the educational instruments adapt to the needs of the student and not the opposite as happens in the transmitting education model. Thus, the role of the teacher in this model will be to mediate knowledge, while the student will be in the center of the process. Such method should allow a greater engagement and stimulation of the students' criticism and reflection turning them into the protagonists and managers of their own learning process. As argued in this article, dialogic communication, decentralized and participatory, is an essential element to make the student an active member in the construction of knowledge. In order to make this process viable, the modules will be organized in a way that instigates the students to be motivated and participative, as well as the appropriation of knowledge through the module. In this sense, the innovation that is proposed is focused on the best performance of the tolls used, which, along with the absolutely updated and consistent content, will guarantee the quality of the course in the distance modality, as it is practiced in the face-to-face modality. Through the instructional design, the theoretical module will adapt the content in images, short videos, podcasts, infographics, symbols, among other materials, in order to facilitate the understanding of the information by the students' different ways of learning. In order to go deep into the relevant themes of the program, videotapes will be recorded in different modalities such as videoanimation and video-interviews with expert professors. Additionally complementary material will provided such as scientific articles that will allow students to make new discoveries regarding the subjects studied. The discussion forum will be the place where the student will be encouraged to engage in the debates that will be promoted on previously studied topics; to share their experiences and doubts; to get closer to the other participants; and the space in which the advising will be carried out. Finally, the evaluation of the student will be formative. Attention will be given to the navigability of the digital platform, to the student participation in debates promoted in the discussion forums and to their performance in the assessment activity. This activity will consist of a research project on a theme to be defined, which will be handed out by the student at the end of the practical module in order to evaluate how was the student's appropriation of the knowledge during the program. As for the performance assessment and effectiveness of the course, from the first edition of the course it will alredy be possible to compare the results with the face-toface course performance. For the distance learning course the following indicators are proposed: navigation in the Moodle Platform, in order not to compromise the student's activity time of correctly work in the Virtual Learning Environment otherwise it could negatively affect the content comprehension; the student-professor relationship, through the discussion forum, should be able to stimulate dialogue, similar to the face-to-face contact and education. Finally, the analysis of the results of these two components of the teachinglearning process in the distance education must necessarily be compared with the good 
performance of students in face-to-face education, in which there are dialogue and active participation of the students.

We agree with the reflections of Prieto Castilho (2000) and Nóvoa (2015) on communication in education and the need to rebuild the culture of debate and criticism. As observed, the diversity of ways of learning, made possible by ICTs, and its alignment with the proposed methodology will enable students from different learning styles to process information into knowledge in a participatory, dialogic and transformative way. Given this perspective, it is considered that teaching methods that allow the establishment of educational, dialogical and plural communication between educational institution and student, plus the learning objects that will compose the program, and that such objects are very close to the ordinary media consumed by the student in the digital world, it will allow the student to participate in the teaching-learning process in the same he/she uses ICT in his/her daily life. This fact will give new meanings to the concept of higher education and will expand the opportunities for knowledge generation in the general society.

\section{The Challenges of Education in the Digital Era}

Based on the reflections and the experience that we presented here, it is up to higher education and education as a whole to develop new practices that are not only aligned with the digital means. More important is to think on methodologies that stimulate mechanisms of self-learning and teamwork and finally abandoning the pedagogy of transmission, a challenge that should be achieved through the establishment of effective dialogue between teachers and students. Such need arises because the current virtual connects people with each other all the time, in a way that school activities in close spaces and oriented towards educational action, are themselves already part of the internet, therefore in the context of cyberspace. As a result, it is necessary that the content of higher education courses receive new meanings so students will be able to integrate in his/her learning process the elements that he/she uses in the digital environment in his/her daily life. This will stimulate the increase of the bond student-university, and it will be tool to prevent dropouts in higher education.

\section{Final Considerations}

The reflections presented in this paper seek to articulate a new method of teaching and learning in order to understand the contemporary demand imposed by ICTs' emersion. In order for this perspective to become possible, higher education needs to discover new forms of dialogues and to establish an educational communication with its students since through this practice it will be possible to abandon the pedagogy of transmission and adopt a plural 
model, consistent with the changes experienced by society. In this sense, the university can and must emphasize the establishment of a new paradigm in the education-student relationship, that of participation, emphasizing collaborative work among all parts, in a horizontal format. Thus in this format, the role of the teacher is to be the driver of the process not the instructor who defines an outdated model of education, provoking lack of motivation and copy of repetitive data, which is valueless to the true purpose that Education should have. It is about working with communication in your favor, in a true Communication / Education binomial. Furthermore, the possibility of using this model in the e-learning modality, presents itself as an important tool for the consolidation of this new proposed model, increasing the number of students who will use it and hence leading to a real democratization of education. Therefore, is for the university to perceive these possibilities for the application of new practices that will allow an effective relationship with the individual, so that the education/ communication process become a reality in a short-term.

\section{References}

Aparici, R. (Org.). (2014). Educomunicação: para além do 2.0. São Paulo, SP: Paulinas.

Associação Brasileira de Educação a Distância. (Org.). (2016). Censo EAD.BR: relatório analítico da aprendizagem a distância no Brasil 2016 = Censo EAD.BR: analytic report of distance learning in Brazil 2016 [Versão digital Adobe Reader] (M. T. M. Abreu, Trad.).Recuperado de http://abed.org.br/censoead2016/Censo_EAD_2016_portugues.pdf. [M. T. M. Abreu, Trad.].

Crovi Druetta, D. (2014). A trama reticular da educação. In. R. Aparici (Org.). Educomunicação: para além do 2.0. (L. M. Reis, Trad.). São Paulo, SP: Paulinas.

Cury, L. Revistando Morin, Comunicação \& Educação Revista do Departamento de Comunicações e Artes da Eca/USP 17(1), 39-37. doi: http://dx.doi.org/10.11606/issn.2316-9125.v17i1p39-47

Cury, L., Sousa, P. C., \& Kudeken, V. S. S, (2017). Proposta de Curso na Modalidade Ead - Introdução à Pesquisa Científica a partir da Disciplina Teoria e Método de Pesquisa em Comunicação da ECA/USP. doi: 10.17143/ciaed/XXIIlCIAED.2017.00420

Frago, A. V., \& Escolano, A. (2001). Currículo, espaço e subjetividade: a arquitetura como programa. Rio de Janeiro, RJ: DP\&A.

Freire, P. (1973). ¿Extension o comunicación?. La conscientización en el medio rural. Buenos Aries, Siglo XXI, 1973.

Gutiérrez A. M. (2014). Criação multimídia e alfabetização na era digital. In. R. Aparici (Org.) Educomunicação: para além do 2.0. (L. M. Reis, Trad.). São Paulo, SP: Paulinas.

KAPLÚN M. (2014). Uma pedagogia da comunicação. In. R. Aparici (Org.). Educomunicação: para além do 2.0. (L. M. Reis, Trad.). São Paulo, SP: Paulinas. 
Nóvoa, A. (2015). Em busca de liberdade nas universidades: para que serve a pesquisa em Educação?. Educação e Pesquisa, 41(1), 263-277, doi: http://dx.doi.org/10.1590/S1517-97022015400100301.

Prieto, D. C. (2000). Comuniccación, universidad, y desarollo. Buenos Aires, Argentina: Plangeco.

Quiroz-Velasco, María-Teresa (2015). Aprendizagens na era digital [recurso electrónico] : dentro e fora da escola. Comunicação \& educação, 20(1), 63-70, doi: http://dx.doi.org/10.11606/issn.2316-9125.v20i1p63-70.

Tibiriçá, Cleonildi. (2015). Por uma reinvenção do diálogo na educação. Tese de doutorado, Universidade de São Paulo, São Paulo, SP, Brasil. Recuperado de http://www.teses.usp.br/teses/disponiveis/27/27154/tde-26062015-155843/pt-br.php. 